Article

\title{
Biomimetic Mineralization of Magnetic Iron Oxide Nanoparticles Mediated by Bi-Functional Copolypeptides
}

\author{
Liu Liu ${ }^{1}$, Ximing Pu ${ }^{1} *$, Guangfu Yin ${ }^{1}$, Xianchun Chen ${ }^{1}$, Jie Yin ${ }^{1,2}$ and Yuhao Wu ${ }^{1}$ \\ 1 College of Materials Science and Engineering, Sichuan University, Chengdu 610065, China; \\ liuliu2019@126.com (L.L.); yingf@scu.edu.cn (G.Y.); kfwcxc@163.com (X.C.); inj21@163.com (J.Y.); \\ 15198006630@163.com (Y.W.) \\ 2 School of Automation and Information Engineering, Sichuan University of Science and Engineering, \\ Zigong 643000, China \\ * Correspondence: puximing@163.com; Tel./Fax: +86-28-8541-3003
}

Academic Editors: Clayton Jeffryes and Si Amar Dahoumane

Received: 14 March 2019; Accepted: 9 April 2019; Published: 10 April 2019

check for updates

\begin{abstract}
Magnetite $\left(\mathrm{Fe}_{3} \mathrm{O}_{4}\right)$ nanoparticles are widely used in multiple biomedical applications due to their magnetic properties depending on the size, shape and organization of the crystals. However, the crystal growth and morphology of $\mathrm{Fe}_{3} \mathrm{O}_{4}$ nanoparticles remain difficult to control without using organic solvent or a high temperature. Inspired by the natural biomineralization process, a 14-mer bi-functional copolypeptide, leveraging the affinity of binding $\mathrm{Fe}_{3} \mathrm{O}_{4}$ together with targeting ovarian cancer cell A2780, was used as a template in the biomimetic mineralization of magnetite. Alongside this, a ginger extract was applied as an antioxidant and a size-conditioning agent of $\mathrm{Fe}_{3} \mathrm{O}_{4}$ crystals. As a result of the cooperative effects of the peptide and the ginger extract, the size and dispersibility of $\mathrm{Fe}_{3} \mathrm{O}_{4}$ were controlled based on the interaction of the amino acid and the ginger extract. Our study also demonstrated that the obtained particles with superparamagnetism could selectively be taken up by $\mathrm{A} 2780$ cells. In summary, the $\mathrm{Fe}_{3} \mathrm{O}_{4}$-QY-G nanoparticles may have potential applications in targeting tumor therapy or angiography.
\end{abstract}

Keywords: $\mathrm{Fe}_{3} \mathrm{O}_{4}$ nanoparticle; biomimetic mineralization; A2780 cell; targeting

\section{Introduction}

$\mathrm{Fe}_{3} \mathrm{O}_{4}$ magnetic nanoparticles ( $\mathrm{Fe}_{3} \mathrm{O}_{4}$-MNPs) have gradually become the concern of researchers because they can be applied in the fields of labeling, magnetic separation of biological materials, Magnetic Resonance Imaging (MRI) contrast enhancement, directed drug delivery, and hyperthermia treatment [1,2]. The properties and applications of $\mathrm{Fe}_{3} \mathrm{O}_{4}-\mathrm{MNPs}$ depend largely on size, crystallinity, and morphology. $\mathrm{Fe}_{3} \mathrm{O}_{4}$-MNPs could display a unique form of magnetism called superparamagnetism [3] when the diameter is below a certain size (generally 25-30 nm), which makes them respond more rapidly and stronger than the bulk magnets in a magnetic field [4]. The nanoparticles retain no residual magnetism at room temperature with negligible coercivity, therefore, these particles could easily be dispersed when the magnetic field is removed, which is conducive to increasing the half-life of the particles in the circulation through escaping from macrophages.

However, the superparamagnetic $\mathrm{Fe}_{3} \mathrm{O}_{4}$-MNPs are easily oxidized in an aqueous solution, which would lead to reuniting. The aggregates of magnetic particles will be removed by phagocytes, or they may cause thrombosis or the blockage of blood capillaries after entering organisms. In addition to this, it is inevitable that some $\mathrm{Fe}_{3} \mathrm{O}_{4}$-MNPs obtained by one-pot method contain large amounts of organic 
solvents, which will limit the applications of the materials in organisms. Therefore, how to prepare $\mathrm{Fe}_{3} \mathrm{O}_{4}$-MNPs with suitable size and excellent dispersibility through a safe and convenient method has become a research hotspot in the biomedical field.

Biomimetic mineralization is a powerful approach to synthesize advanced materials with controlled size, shape, and polymorph under ambient conditions and pressure in an aqueous environment, using biological macromolecules (peptide, protein, DNA, etc.) as templates [5-7]. Many proteins / peptides have been well developed for metal nanoparticle (NP) biosynthesis, such as Au NPs [8,9] and Gd NPs [10], along with the associated synthetic theories. As well as this, there were studies conducted on the biosynthesis of $\mathrm{Fe}_{3} \mathrm{O}_{4}$ or $\mathrm{Fe}_{2} \mathrm{O}_{3}$. For example, Mms6 [11], a magnetosome-associated protein derived from Magnetospirillum magneticum strain AMB-1, regulated $\mathrm{Fe}_{3} \mathrm{O}_{4}$ crystal morphology and promoted the formation of superparamagnetic $\mathrm{Fe}_{3} \mathrm{O}_{4}$-MNPs of uniform size and shape. Also, block copolypeptides poly( $\left(\mathrm{EG}_{2} \text {-lys }\right)_{100}$-b-poly $(\mathrm{asp})_{30}$ [12] were used as a coating to stabilize clusters of $\mathrm{Fe}_{2} \mathrm{O}_{3}$-MNPs and control their sizes in an aqueous environment. Therefore, it is speculated that functional biological molecules (e.g., targeting peptide [13], polypeptide with a therapeutic effect [14], protein, or biopolymer capable of improving biocompatibility [15]) can be introduced in the process of biomimetic mineralization so that the specific functions can be endowed at the same time as $\mathrm{Fe}_{3} \mathrm{O}_{4}$-MNPs are being formed.

Green chemistry synthesis methods for nanoparticles have positive aspects compared with chemical methods, such as safety, environment amity, and no use of harmful compounds [16]. Plant extracts are generally considered reducing and stabilizing agents for the synthesis of metal nanoparticles with specific shapes and sizes [17-19]. The phytochemicals including hydroxyl, carboxyl, and amino functional groups can be regarded as effective metal-reducing agents. They can both improve the stability of nanoparticles and give rise to a cooperative effect when the nanoparticles are used for biomedical applications. Among them, ginger extract has attracted attention because of its chemical and biological properties such as antioxidant, antibacterial activity, and anti-inflammatory effects [20]. Ginger is a common condiment for various foods and beverages. As a functional food, ginger has been recognized for its health benefits [21]. It has long history of medical use in many countries. Besides minerals such as iron, calcium, phosphorous, zinc, copper, chromium and manganese, ginger also contains dietary fiber and sugar, lipids vitamins, and amino acids. The components are harmless to the human body. The microstructure of ginger extract has also been confirmed to increase the stability of synthetic material [22].

In this work, $\mathrm{Fe}_{3} \mathrm{O}_{4}$ nanoparticles $\left(\mathrm{Fe}_{3} \mathrm{O}_{4}-\mathrm{QY}-\mathrm{G}\right)$ with good targeting performance and morphology were prepared by biomimetic mineralization in a mild condition using 14-mer peptide (QQTNWSLTVNFKLY, QY) as templates together with the ginger extract. This 14-mer peptide was designed in a predetermined manner, which consisted of a peptide (TVNFKLY, TVN) with $\mathrm{Fe}_{3} \mathrm{O}_{4}$-MNPs affinity [23] and a peptide (QQTNWSL, QQT) which targets the ovarian carcinoma cell A2780. These 7-mer peptides were screened previously using phage display peptide library technology.

\section{Results}

\subsection{Characterization of Mineral Phases}

Firstly, to verify that peptide TVNFKLY (TVN) could mediate the formation of $\mathrm{Fe}_{3} \mathrm{O}_{4}$, $\mathrm{Fe}_{3} \mathrm{O}_{4}$-peptide nanoparticles were prepared using the method described in 4.2 with different concentrations of TVN and a random peptide named SVE (the specific data is shown in the supporting information, Figure S1). As shown in Figure 1, the $\mathrm{Fe}_{3} \mathrm{O}_{4}$-TVN nanoparticles presented good dispersibility and uniform size (details are presented in the supporting information, Figure S1b). The TVN peptide was combined with an ovarian carcinoma cell A2780 specific targeting peptide (QQT) to construct a 14-mer bi-functional copolypeptide (QY) which was expected to possess both the affinity of binding $\mathrm{Fe}_{3} \mathrm{O}_{4}$ and targeting the ovarian cancer cell A2780. In the following sections, the $\mathrm{Fe}_{3} \mathrm{O}_{4}$ nanoparticles prepared by simultaneously using the QY peptide and ginger extract are referred to 
as $\mathrm{Fe}_{3} \mathrm{O}_{4}$-QY-G, while the $\mathrm{Fe}_{3} \mathrm{O}_{4}$ nanoparticles prepared by using the QY peptide are referred to as $\mathrm{Fe}_{3} \mathrm{O}_{4}$-QY (the relevant data on concentration investigation is shown in the supporting information, Figure S4).
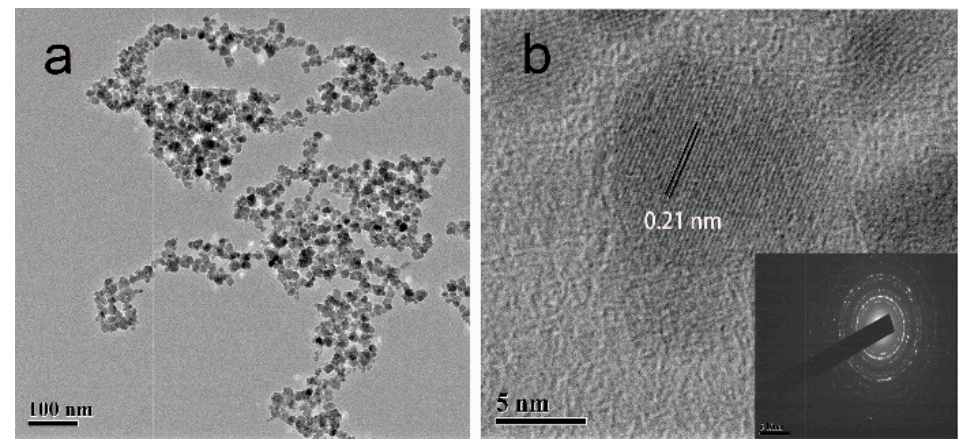

Figure 1. (a) Transmission electron microscopy (TEM) and (b) high-resolution transmission electron microscopy (HR TEM) images of $\mathrm{Fe}_{3} \mathrm{O}_{4}$ nanoparticles prepared with TVNFKLY (TVN) peptide.

The results of X-ray diffraction (XRD), X-ray photoelectron spectroscop (XPS) and Raman spectroscopy showed that all the $\mathrm{Fe}_{3} \mathrm{O}_{4}$ nanoparticles were cubic inverse spinel structure. This means that the addition of the peptide and ginger extract have no significant influence on the crystal structure of $\mathrm{Fe}_{3} \mathrm{O}_{4}$. The XRD pattern of $\mathrm{Fe}_{3} \mathrm{O}_{4}-\mathrm{QY}-\mathrm{G}$ nanoparticles is shown in Figure 2a. The characteristic peaks at $30.1^{\circ}, 35.69^{\circ}, 43.24^{\circ}, 57.13^{\circ}$, and $62.77^{\circ}$ were corresponding to the (220), (311), (400), (511), and (440) crystal planes of $\mathrm{Fe}_{3} \mathrm{O}_{4}$ (Joint Committee on Powder Diffraction Standards (JCPDS) No.89-3854), respectively. With the XRD pattern, the average diameter which could be evaluated from the Scherrer equation ( $\mathrm{D}=K \lambda / \beta \cos \theta$, where $K$ is a constant (0.89), $\lambda$ is the $X$-ray wavelength (1.54060 $\AA$ ), $\beta$ is the peak width of half-maximum, and $\theta$ is the Bragg diffraction angle) and was obtained as 6-12 nm. In addition, the broad peak in the $5-23^{\circ}$ range was speculated to be organic compounds from the ginger extract [24]. The peaks shown at $517 \mathrm{~cm}^{-1}$ and $680 \mathrm{~cm}^{-1}$ in Figure $2 \mathrm{~b}$ were typical Raman scattering peaks of $\mathrm{Fe}_{3} \mathrm{O}_{4}[25,26]$ and the peaks at $1400 \mathrm{~cm}^{-1}$ and $1580 \mathrm{~cm}^{-1}$ were the characteristic peaks of $\gamma-\mathrm{Fe}_{2} \mathrm{O}_{3}$ [27], which revealed that $\mathrm{Fe}_{3} \mathrm{O}_{4}$ was oxidized to $\mathrm{Fe}_{2} \mathrm{O}_{3}$ under the heating condition [28]. From Figure $2 c-e$, it can be seen that the peak positions of $\mathrm{Fe} 2 \mathrm{p}_{3 / 2}$ and $\mathrm{Fe} 2 \mathrm{p}_{1 / 2}$ are located at around $710.34 \mathrm{eV}$ and $724.11 \mathrm{eV}$, respectively. The $\mathrm{Fe} 2 \mathrm{p}_{3 / 2}$ peak can be well fitted by peaks of octahedral ferrous iron [Fe (II) oct.], octahedral ferric iron [Fe (III) oct.], and tetrahedral ferric iron [Fe (III) tet.]. The $\mathrm{Fe}$ (II)/ $\mathrm{Fe}$ (III) ratio of $\mathrm{Fe}_{3} \mathrm{O}_{4}$ (Figure 2c), $\mathrm{Fe}_{3} \mathrm{O}_{4}$-QY nanoparticles (Figure 2d), and $\mathrm{Fe}_{3} \mathrm{O}_{4}$-QY-G nanoparticles (Figure 2e) were $0.503,0.498$ and 0.501 , respectively. All of these matched the theoretical value of $\mathrm{Fe}_{3} \mathrm{O}_{4}$. Moreover, no shakeup satellite peaks, which are the fingerprints of the electronic structures of iron oxides such as $\alpha-\mathrm{Fe}_{2} \mathrm{O}_{3}$ and $\gamma-\mathrm{Fe}_{2} \mathrm{O}_{3}$, can be identified. This indicates that $\mathrm{Fe}_{2} \mathrm{O}_{3}$ does not present in the nanoparticles. 

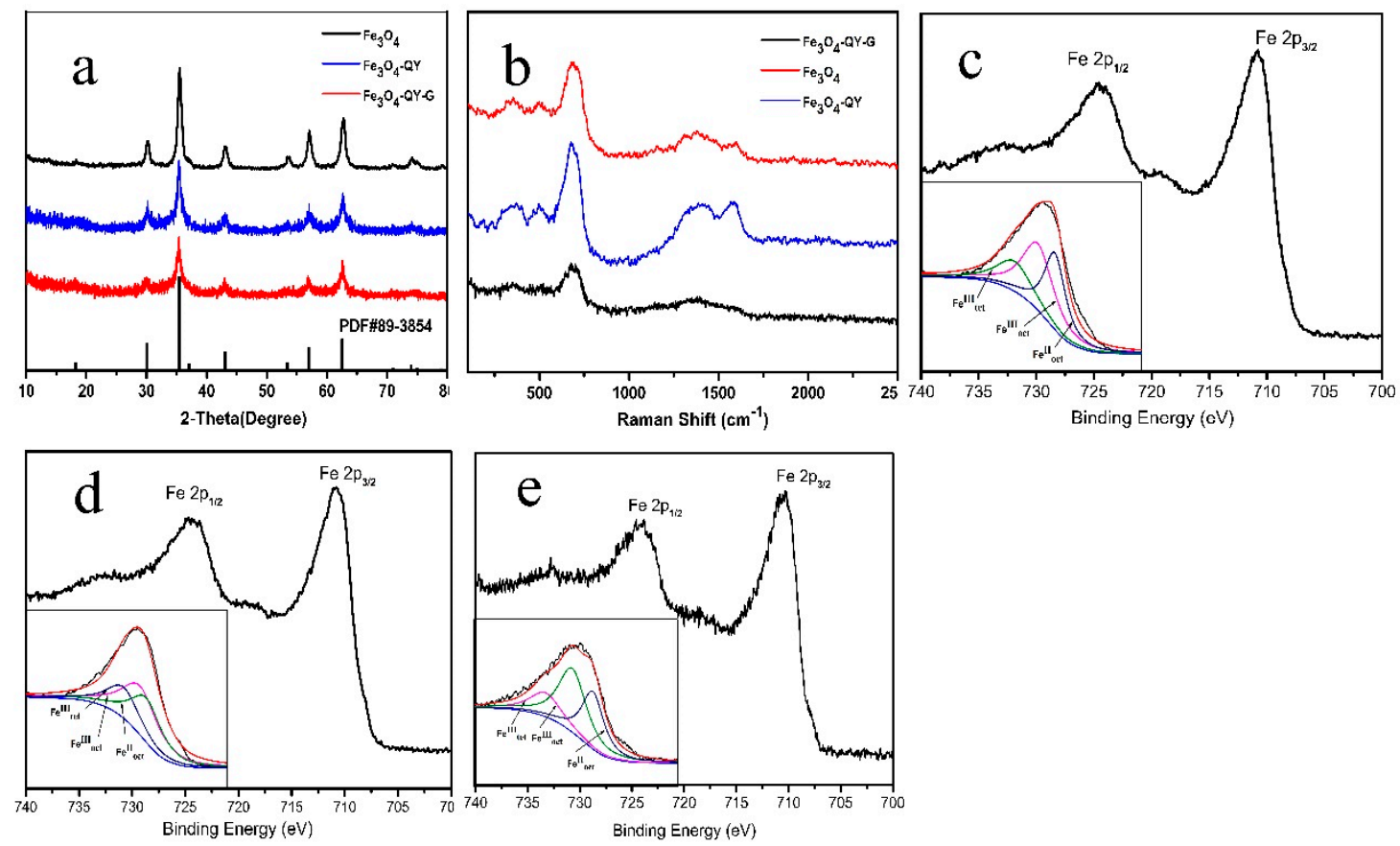

Figure 2. (a) XRD pattern of $\mathrm{Fe}_{3} \mathrm{O}_{4}, \mathrm{Fe}_{3} \mathrm{O}_{4}$-QY, $\mathrm{Fe}_{3} \mathrm{O}_{4}$-QY-G nanoparticles, (b) Raman spectrum of $\mathrm{Fe}_{3} \mathrm{O}_{4}, \mathrm{Fe}_{3} \mathrm{O}_{4}$-QY, $\mathrm{Fe}_{3} \mathrm{O}_{4}$-QY-G nanoparticles, XPS Fe 2p core-level spectra of (c) $\mathrm{Fe}_{3} \mathrm{O}_{4}$, (d) $\mathrm{Fe}_{3} \mathrm{O}_{4}$-QY, (e) $\mathrm{Fe}_{3} \mathrm{O}_{4}$-QY-G.

\subsection{Constituent Analysis via FT-IR}

Figure 3 shows an FT-IR image of $\mathrm{Fe}_{3} \mathrm{O}_{4}$ nanoparticles, 14-mer peptide, ginger extract, and $\mathrm{Fe}_{3} \mathrm{O}_{4}$-QY-G nanoparticles. Ginger contains a complex chemical composition: In addition to dietary fiber and sugar, it also contains specific compounds-gingerol $\left(\mathrm{C}_{17} \mathrm{H}_{26} \mathrm{O}_{4}\right)$, minerals, flavonoids, lipids, vitamins, and amino acids [29,30]. Complex peaks in the range of 400-800 $\mathrm{cm}^{-1}$ may be mineral compounds, most of which contain $\mathrm{K}, \mathrm{Mg}, \mathrm{P}, \mathrm{Ca}$, and $\mathrm{Na}$ elements [31]. The peaks at $1320-1420 \mathrm{~cm}^{-1}$ were related to $\mathrm{O}-\mathrm{H}$ bending vibrations of the phenolic group and $\mathrm{C}-\mathrm{H}$ bending vibrations (saccharides, gingerol, flavonoids, and vitamins). The peak at $1077 \mathrm{~cm}^{-1}$ may be prescribed to $\mathrm{C}=\mathrm{O}$ stretching vibrations of organic compounds (mainly saccharides) [32]. The strong broad peaks centered at $3400 \mathrm{~cm}^{-1}$ were ascribed to the stretching vibrations of $\mathrm{H}$-bonded $\mathrm{O}-\mathrm{H}$ groups. The peaks at $1640 \mathrm{~cm}^{-1}$ were related to $\mathrm{H}_{2} \mathrm{O}$ bending vibrations. The comparison of peak intensity showed that the ginger extract was mainly composed from saccharides (including starch) with admixtures of mineral components and phenolic compounds. With respect to the peptide, the amide I band results from the stretching vibration of the peptide carbonyl group $(\mathrm{C}=\mathrm{O})$; the native spectrum of this band shows three components positioned at $1633 \mathrm{~cm}^{-1}, 1643 \mathrm{~cm}^{-1}$, and $1660 \mathrm{~cm}^{-1}$ [22].

For the $\mathrm{Fe}_{3} \mathrm{O}_{4}$-QY-G nanoparticles, the band at $1532 \mathrm{~cm}^{-1}$ was attributed to amide II. The peak at $1077 \mathrm{~cm}^{-1}$ may be prescribed to the ginger extract. The broad peak at $570 \mathrm{~cm}^{-1}$ belonged to stretching vibrations of $\mathrm{Fe}-\mathrm{O}$ in $\mathrm{Fe}_{3} \mathrm{O}_{4}$.

The difference in peak intensity among the ginger extract, peptide, and $\mathrm{Fe}_{3} \mathrm{O}_{4}$ nanoparticles points to the selective adsorption of the ginger extract and peptide on the nanoparticle surface. Aside from this, the peaks at $1660 \mathrm{~cm}^{-1}$ and $1433 \mathrm{~cm}^{-1}$ which were related to the amide I and the amide III, respectively, disappeared in the $\mathrm{Fe}_{3} \mathrm{O}_{4}$-QY-G nanoparticles. The peak at $1410 \mathrm{~cm}^{-1}$ shifted to $1340 \mathrm{~cm}^{-1}(\mathrm{C}-\mathrm{H}$ bending vibration). The disappearance of amide bonds may have been caused by $\mathrm{C}=\mathrm{O}$ forming a hydrogen bond with the -OH enriched on the surface of $\mathrm{Fe}_{3} \mathrm{O}_{4}$. Specifically, the iron atoms in the surface of the $\mathrm{Fe}_{3} \mathrm{O}_{4}$ atomic lattice may coordinate with water molecules in an aqueous solution and form $-\mathrm{OH}$, which could form hydrogen bonds with the $\mathrm{C}=\mathrm{O}$ from amide. Meanwhile, the peak at 
$3400 \mathrm{~cm}^{-1}$ of the $\mathrm{Fe}_{3} \mathrm{O}_{4}$-QY-G nanoparticles had a larger intensity than that of the $\mathrm{Fe}_{3} \mathrm{O}_{4}$ nanoparticles, which indicated an increased hydrophilicity of the prepared material.

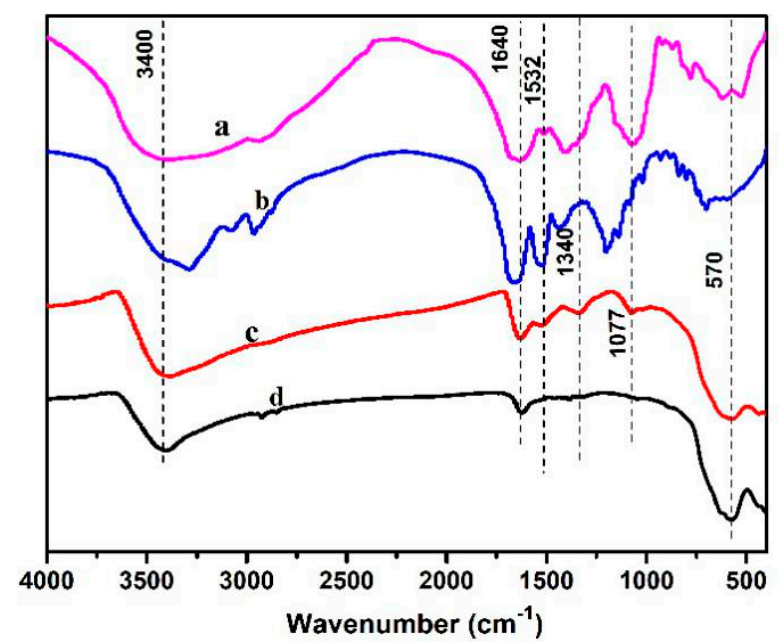

Figure 3. FT-IR spectra of (a) ginger extract, (b) peptide (QY), (c) $\mathrm{Fe}_{3} \mathrm{O}_{4}$-QY-G nanoparticles, (d) $\mathrm{Fe}_{3} \mathrm{O}_{4}$ nanoparticles.

\subsection{Morphology and Solvent-Dependent Stability}

To observe the stability of the different materials, water and human serum were used as dispersants. As shown in Figure $4 \mathrm{a}-\mathrm{f}$, after incubation for $48 \mathrm{~h}$, the $\mathrm{Fe}_{3} \mathrm{O}_{4}$ nanoparticles completely settled in the aqueous phase while $\mathrm{Fe}_{3} \mathrm{O}_{4}$-QY-G nanoparticles were stable with only a slight subsidence. As a dispersion medium, the serum would reduce the sedimentation rate of nanoparticles because of its viscosity. In addition to this, the residual phenolic groups contained in the ginger extract may protect $\mathrm{Fe}_{3} \mathrm{O}_{4}$ from oxidization and slow down the aggregation and sedimentation rate. As demonstrated above, the $\mathrm{Fe}_{3} \mathrm{O}_{4}$-QY-G nanoparticles are more stable than $\mathrm{Fe}_{3} \mathrm{O}_{4}$ nanoparticles in the same condition.

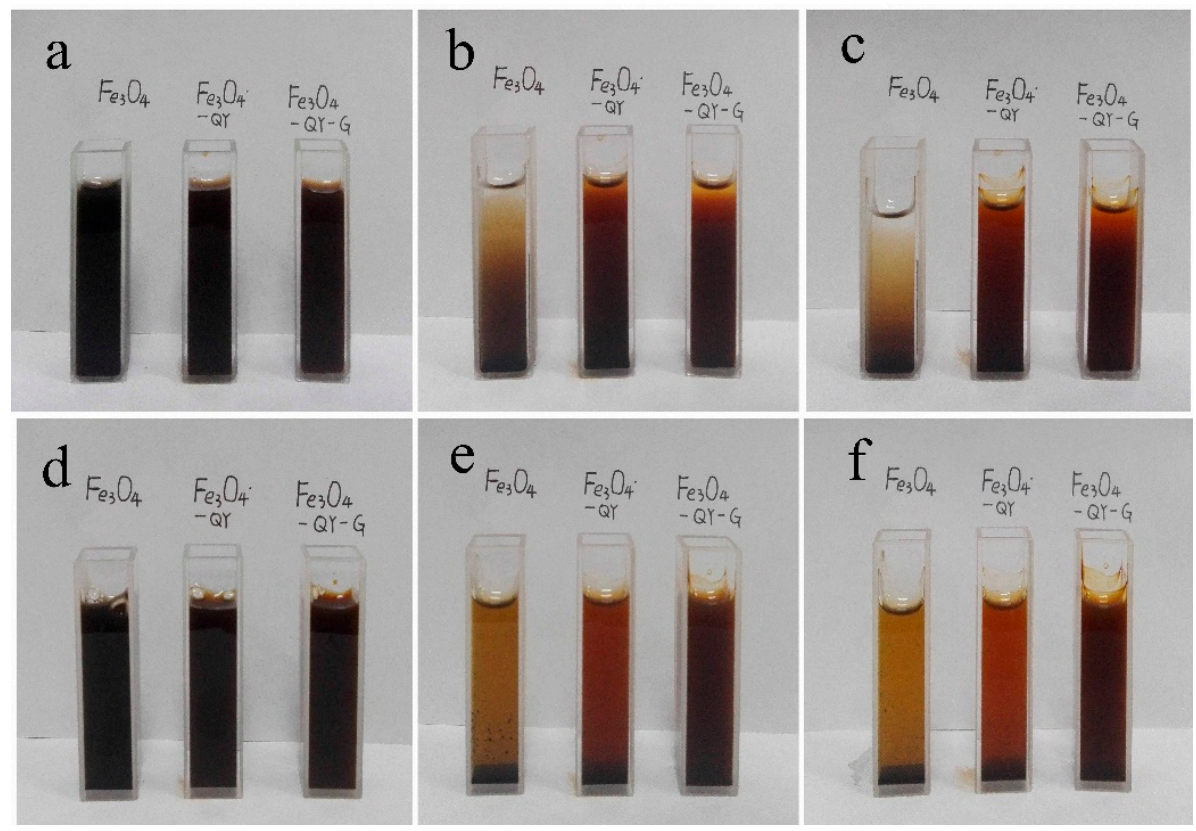

Figure 4. Solvent-dependent stability pictures of nanoparticles (a) $0 \mathrm{~h}$ in water, (b) $24 \mathrm{~h}$ in water, (c) $48 \mathrm{~h}$ in water, (d) $0 \mathrm{~h}$ in human serum, (e) $24 \mathrm{~h}$ in human serum, (f) $48 \mathrm{~h}$ in human serum. 
Additionally, the lysine $(\mathrm{K})$ and asparagine $(\mathrm{N})$ side chains in the 14-mer peptide can spontaneously form chemically stable amide bonds, namely isopeptide bonds [33-35]. The isopeptide bonds decrease the effect of hydrolytic degradation, and increase the stability of the peptide linkage and the affinity for the targeting ligand, which is favorable for the subsequent application of the material. Since $\mathrm{Fe}_{3} \mathrm{O}_{4}$-QY-G nanoparticles show greater stability than the $\mathrm{Fe}_{3} \mathrm{O}_{4}$-QY nanoparticles, the subsequent characterizations mainly focus on $\mathrm{Fe}_{3} \mathrm{O}_{4}$-QY-G.

TEM observation was used to examine the difference in particle size among the samples. The TEM image shows that $\mathrm{Fe}_{3} \mathrm{O}_{4}-\mathrm{QY}-\mathrm{G}$ nanoparticles (Figure $5 \mathrm{c}$ ) were of a small size. However, glomeration occurred because the extremely small particle size can access greater specific surface area and surface energy. The average particle size was about $7 \mathrm{~nm}$, and the $\mathrm{Fe}_{3} \mathrm{O}_{4}$-QY nanoparticles (Figure $5 \mathrm{~b}$ ) showed a diameter of around $10 \mathrm{~nm}$. While under the same condition, the $\mathrm{Fe}_{3} \mathrm{O}_{4}$ nanoparticles (Figure 5a) prepared by the coprecipitation method had a diameter of about $15 \mathrm{~nm}$, and aggregated severely.
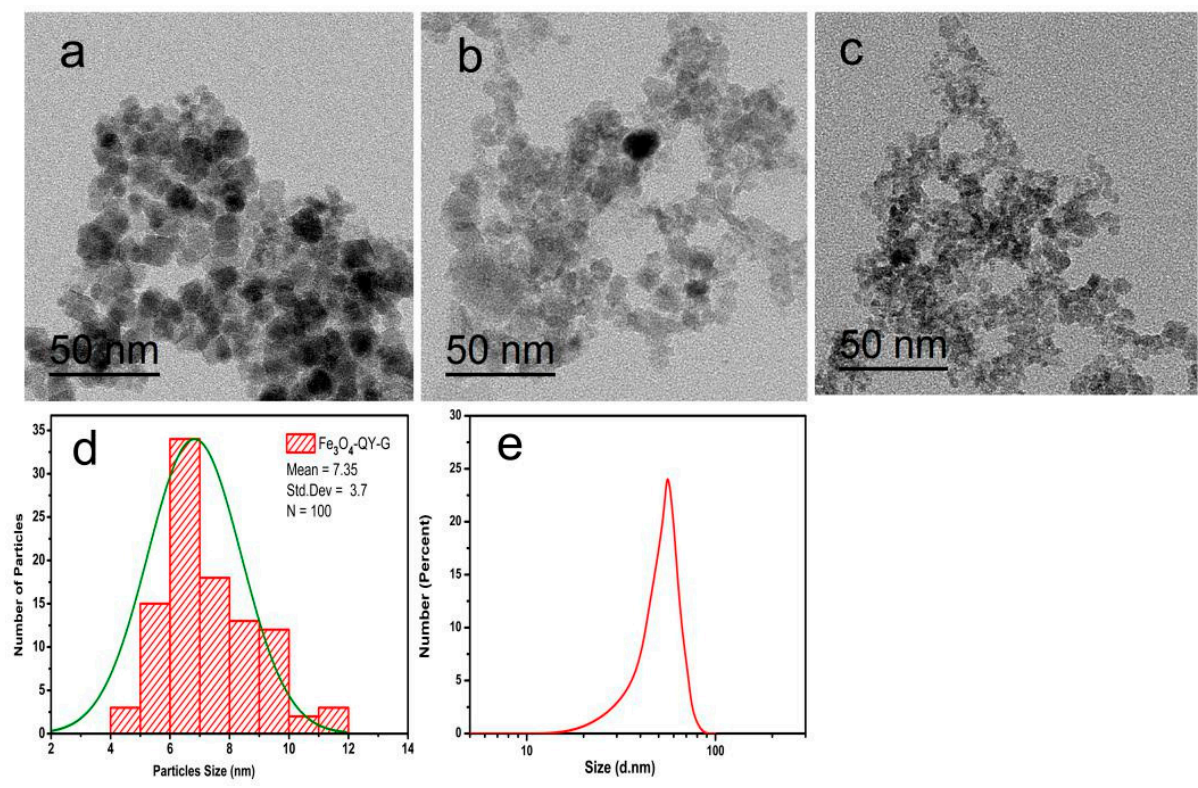

Figure 5. TEM images of nanoparticles: (a) $\mathrm{Fe}_{3} \mathrm{O}_{4}$, (b) $\mathrm{Fe}_{3} \mathrm{O}_{4}-\mathrm{QY}$, (c) $\mathrm{Fe}_{3} \mathrm{O}_{4}-\mathrm{QY}-\mathrm{G}$, (d) corresponding size distribution of $\mathrm{Fe}_{3} \mathrm{O}_{4}$-QY-G nanoparticles, (e) hydrodynamic diameter of $\mathrm{Fe}_{3} \mathrm{O}_{4}$-QY-G nanoparticles.

As shown in Figure $5 \mathrm{c}$, the particle size distribution curve of $\mathrm{Fe}_{3} \mathrm{O}_{4}-\mathrm{QY}-\mathrm{G}$ indicated that the mean diameter size of the nanoparticles was $7.35 \pm 3.7 \mathrm{~nm}$. The XRD pattern suggested that the unassigned peaks may indicate the crystallization of the bio-organic phase present in the extract, which was also observed from the TEM image. The good correlation between particle sizes obtained from the Scherrer equation and TEM supports the crystalline structure of the iron nanoparticles. Zeta-potential and dynamic light scattering (DLS) are additional characterization methods to further determine the dispersion and stability of the $\mathrm{Fe}_{3} \mathrm{O}_{4}-\mathrm{QY}-\mathrm{G}$ nanoparticles. DLS measurement (Figure 5e) indicated that these samples render suspension with a mean hydrodynamic diameter of about $55.28 \mathrm{~nm}$ due to the presence of associated and hydrated organic layers [36]. As DLS is weighted towards large sizes, the average diameter could be higher than those obtained from TEM. However, the average hydrodynamic diameter and the feature that Polydispersity Index (PDI) $=0.102$ hardly varied with time could reveal the excellent stability of $\mathrm{Fe}_{3} \mathrm{O}_{4}-\mathrm{QY}-\mathrm{G}$ nanoparticles. In addition to this, the highly negative value of zeta-potential of these functionalized nanoparticles in water $(\zeta=-18.9 \mathrm{mV})$ also indicated good stability. When the particles are stabilized by purely electrostatic repulsion, an absolute zeta potential value of more than $25 \mathrm{mV}$ is ideal for good kinetic stability at room temperature. However, in the presence of other forces such as steric and hydrogen bonding interactions, the stability can be achieved even at low surface potentials [37]. 


\subsection{Magnetic Property and Imaging Efficiency}

The magnetization curves of $\mathrm{Fe}_{3} \mathrm{O}_{4}, \mathrm{Fe}_{3} \mathrm{O}_{4}-\mathrm{QY}$, and $\mathrm{Fe}_{3} \mathrm{O}_{4}-\mathrm{QY}-\mathrm{G}$ nanoparticles obtained by Vibrating Sample Magnetometer (VSM) at room temperature are shown in Figure 6a-c. The $\mathrm{Fe}_{3} \mathrm{O}_{4}-\mathrm{QY}$ and $\mathrm{Fe}_{3} \mathrm{O}_{4}$-QY-G nanoparticles exhibited the characteristics of superparamagnetism. The coercivity (Hc) and saturation magnetization (Ms) of $\mathrm{Fe}_{3} \mathrm{O}_{4}-\mathrm{QY}-\mathrm{G}$ nanoparticles were 0.35 Oe and $48.9 \mathrm{emu} / \mathrm{g}$, respectively (Figure 6c). As for the $\mathrm{Fe}_{3} \mathrm{O}_{4}$-QY nanoparticles, the Ms and Hc were $58.2 \mathrm{emu} / \mathrm{g}$ and $4.52 \mathrm{Oe}$, respectively (Figure 6b). Both of these Ms values were lower than that of $\mathrm{Fe}_{3} \mathrm{O}_{4}$ nanoparticles prepared by coprecipitation $(72.5 \mathrm{emu} / \mathrm{g}$, Figure $6 \mathrm{a})$. In addition to the adsorption of organic compounds and peptide on nanoparticles (including physical and chemical adsorption), the decrease of saturation magnetization may also be attributable to the size and surface effect. For particles smaller than $10 \mathrm{~nm}$, saturation magnetization is smaller, most likely due to the surface spin canting of the small magnetic nanoparticles.
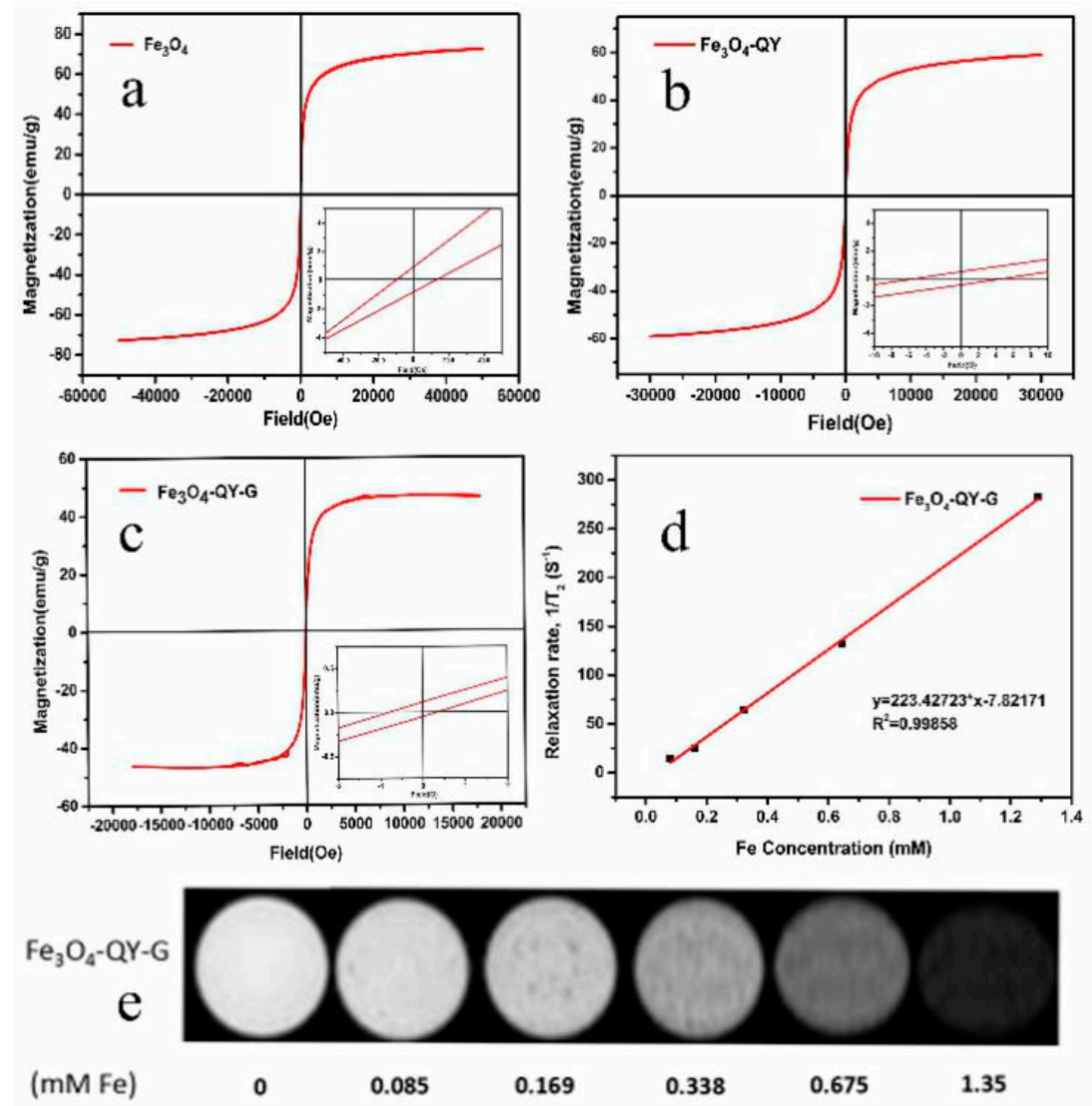

Figure 6. Magnetization curves of (a) $\mathrm{Fe}_{3} \mathrm{O}_{4}$, (b) $\mathrm{Fe}_{3} \mathrm{O}_{4}$-QY, (c) $\mathrm{Fe}_{3} \mathrm{O}_{4}-\mathrm{QY}-\mathrm{G}$ nanoparticles; (d) $\mathrm{T}_{2}$ relaxation rates as a function of iron concentration, (e) $\mathrm{T}_{2}$-weighted Magnetic Resonance (MR) images of $\mathrm{Fe}_{3} \mathrm{O}_{4}$-QY-G nanoparticles with different Fe concentration.

Since superparamagnetic $\mathrm{Fe}_{3} \mathrm{O}_{4}$-MNPs are highly sensitive to external magnetic fields, they are widely used as a contrast agent. Superparamagnetic nanoparticles with strong magnetic moments can locally amplify the external magnetic field to make it non-uniform and shorten the $\mathrm{T}_{2}$ relaxation time of the tissue. Figure 6 shows (d) $\mathrm{T}_{2}$ relaxation rates as a function of iron concentration, and (e) a series of $\mathrm{T}_{2}$-weighted MR images of $\mathrm{Fe}_{3} \mathrm{O}_{4}$-QY-G nanoparticles with different Fe concentration. Taking the slope of a linear fit of $1 / \mathrm{T}_{2}$ vs. Fe concentration, the transverse relaxivity $\left(\mathrm{r}_{2}\right)$ value of $\mathrm{Fe}_{3} \mathrm{O}_{4}-\mathrm{QY}-\mathrm{G}$ in $5 \%$ agarose was $223 \mathrm{mM}^{-1} \mathrm{~S}^{-1}$, which was two times higher than that of Feraheme (ferumoxytol, iron oxide nanoparticles with an $\mathrm{r}_{2}$ value of $98.4 \mathrm{mM}^{-1} \mathrm{~S}^{-1}$ at $7 \mathrm{~T}$ ). Therefore, the $\mathrm{Fe}_{3} \mathrm{O}_{4}$-QY-G nanoparticles have great potential in the application of contrast agents. 


\subsection{The Chelating Ability and Reduction Capability Results of Ginger Extract}

Chen and Ahn [38] found that natural phenolics including quercetin, rutin, catechin, and caffeic acid could be used as a $\mathrm{Fe}^{2+}$-chelator. The data revealed that ginger extract could also function as a $\mathrm{Fe}^{2+}$-chelator because of its natural phenols. Figure 7a shows that the chelating activity of ginger extract on $\mathrm{Fe}^{2+}$ is concentration-dependent. When a small amount of ginger extract $(0.1-2 \mathrm{mg} / \mathrm{mL})$ was added to the reaction system, it could suppress reactivity by occupying the coordination sites of metal ions due to its ferrous ion chelation.
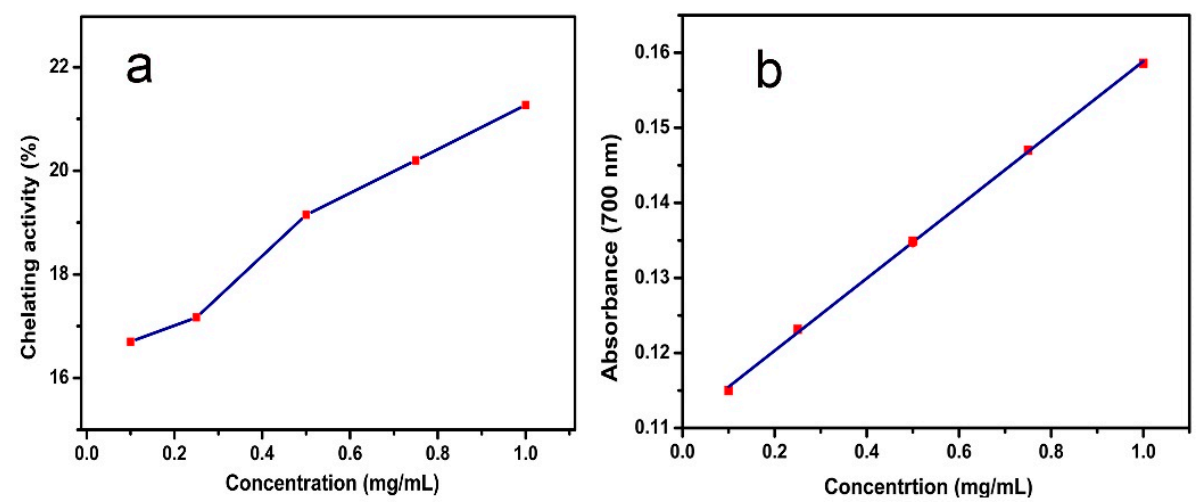

Figure 7. (a) The chelating ability on $\mathrm{Fe}^{2+}$ of ginger extract; (b) the reduction capability of $\mathrm{Fe}^{3+}$ of ginger extract.

In addition to this, as is well-known, the oxidation resistance mechanism of phenolic antioxidants is based on donating an electron to a free radical from $\mathrm{OH}$ - groups attached to the phenolic rings. The mechanism of gingerol antioxidant activity is considered to be similar to that of piperine and curcumin. It is correlated to the phenolic $\mathrm{OH}$ - group and the $\mathrm{CH}_{2}$ - group of the $\beta$-diketone moiety. The free radical can undergo electron transfer or abstract an $\mathrm{H}$ - atom from either of these two sites of gingerol molecule. The ability of the extract to reduce iron (III) was assessed by the method of Oyaizu [39]. In this method, antioxidants form a colored complex with $\mathrm{K}_{3}\left[\mathrm{Fe}(\mathrm{CN})_{6}\right]$ in the presence of trichloroacetic acid and ferric chloride. Measured at $700 \mathrm{~nm}$, an increase in the absorbance of the reaction mixture indicates the reducing power of the sample. At lower concentrations $(0.1-2 \mathrm{mg} / \mathrm{mL})$, the reducing ability of ginger extract to $\mathrm{Fe}^{3+}$ was correlated with its concentration. Along with an increase in extract concentration, the ability to reduce the $\mathrm{Fe}^{3+}$ is also strengthened (Figure $\mathrm{7b}$ ).

\subsection{Cell Targeting and Cytotoxicity Analysis}

The targeting ability of $\mathrm{Fe}_{3} \mathrm{O}_{4}$-QY and $\mathrm{Fe}_{3} \mathrm{O}_{4}$-QY-G nanoparticles to tumor cells was preliminarily examined through Prussian blue staining. In Figure 8, a strong adsorption of $\mathrm{Fe}_{3} \mathrm{O}_{4}$-QY and $\mathrm{Fe}_{3} \mathrm{O}_{4}$-QY-G nanoparticles was observed in A2780 cells, while there was only a slight adsorption of $\mathrm{Fe}_{3} \mathrm{O}_{4}$ nanoparticles in the same condition. Moreover, the L929 cells were used as a control, and there was no significant adsorption of nanoparticles. The results above preliminarily proved that the $\mathrm{Fe}_{3} \mathrm{O}_{4}$-QY and $\mathrm{Fe}_{3} \mathrm{O}_{4}$-QY-G nanoparticles have targeting behavior to $\mathrm{A} 2780$ cells due to the peptide (QY) and the addition of ginger extract did not significantly affect the targeting ability of the materials.

To further study the targeting specificity of the $\mathrm{Fe}_{3} \mathrm{O}_{4}-\mathrm{QY}-\mathrm{G}$ nanoparticles, the nanoparticles were incubated with A2780 cells and L929 cells. Figure 9 shows the Fe uptake of $\mathrm{Fe}_{3} \mathrm{O}_{4}$-QY-G nanoparticles by A2780 cells, which is about 4.86-fold higher that by L929 cells. As in the group of $\mathrm{Fe}_{3} \mathrm{O}_{4}$ nanoparticles, no significant difference was observed for iron uptake in either A2780 cells or L929 cells. The quantitative results by Inductively Coupled Plasma Optical Emission Spectrometer (ICP-OES) analysis are consistent with the qualitative data by microscope. Thus, the obtained $\mathrm{Fe}_{3} \mathrm{O}_{4}$-QY-G nanoparticles are anticipated to have great potential for use in the field of cancer diagnosis and treatment. 


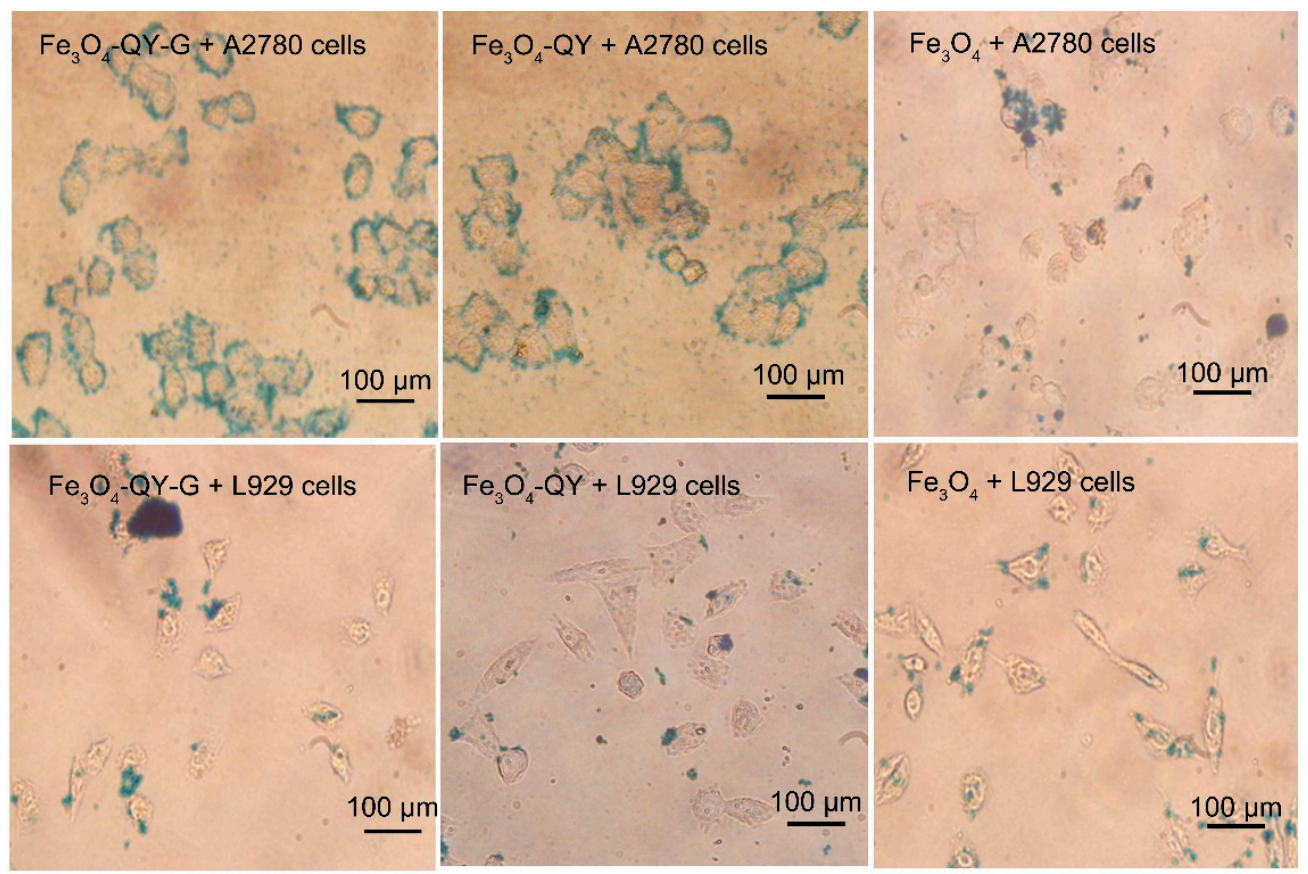

Figure 8. Prussian blue staining images of A2780 and L929 cells incubated with $\mathrm{Fe}_{3} \mathrm{O}_{4}-\mathrm{QY}-\mathrm{G}, \mathrm{Fe}_{3} \mathrm{O}_{4}-\mathrm{QY}$, or $\mathrm{Fe}_{3} \mathrm{O}_{4}$ nanoparticles for $4 \mathrm{~h}$.

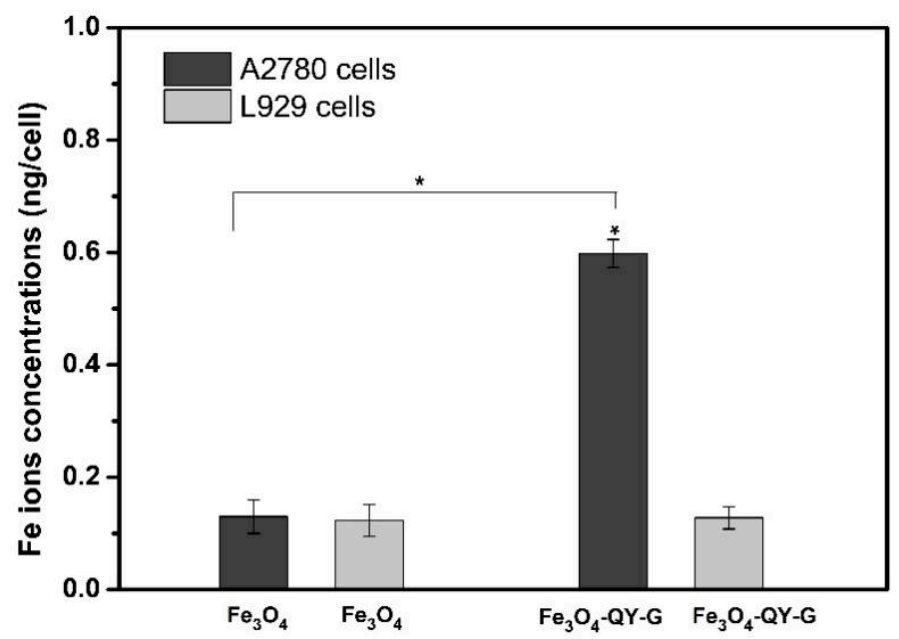

Figure 9. The Fe ion concentration in each A2780 and L929 cell after co-cultured with $\mathrm{Fe}_{3} \mathrm{O}_{4}-\mathrm{QY}-\mathrm{G}$ and $\mathrm{Fe}_{3} \mathrm{O}_{4}$ nanoparticles for $24 \mathrm{~h}$ at a concentration of $100 \mu \mathrm{g} / \mathrm{mL}$ in the medium, ${ }^{*}$ shows significant differences between the corresponding groups, ${ }^{*} p<0.05$.

Figure 10 shows the cell viability after incubation with different concentrations of $\mathrm{Fe}_{3} \mathrm{O}_{4}$-QY-G nanoparticles and $\mathrm{Fe}_{3} \mathrm{O}_{4}$ nanoparticles. It can be seen that the cell viability of A2780 cells was not significantly affected at the concentrations of $25-100 \mu \mathrm{g} / \mathrm{mL}$ after $24 \mathrm{~h}$. While the concentration increased to $200 \mu \mathrm{g} / \mathrm{mL}$, both the two materials showed a little cytotoxicity. When the co-culture time reached $48 \mathrm{~h}$, the cells exposed to the $\mathrm{Fe}_{3} \mathrm{O}_{4}$-QY-G nanoparticles were fewer than those exposed to the $\mathrm{Fe}_{3} \mathrm{O}_{4}$ nanoparticles and the control. These results indicated that the $\mathrm{Fe}_{3} \mathrm{O}_{4}$-QY-G nanoparticles could inhibit A2780 cell proliferation. With regard to the L929 cells (Figure 10b), there was no significant cytotoxicity seen in both groups of $\mathrm{Fe}_{3} \mathrm{O}_{4}-\mathrm{QY}-\mathrm{G}$ nanoparticles and $\mathrm{Fe}_{3} \mathrm{O}_{4}$ nanoparticles. 

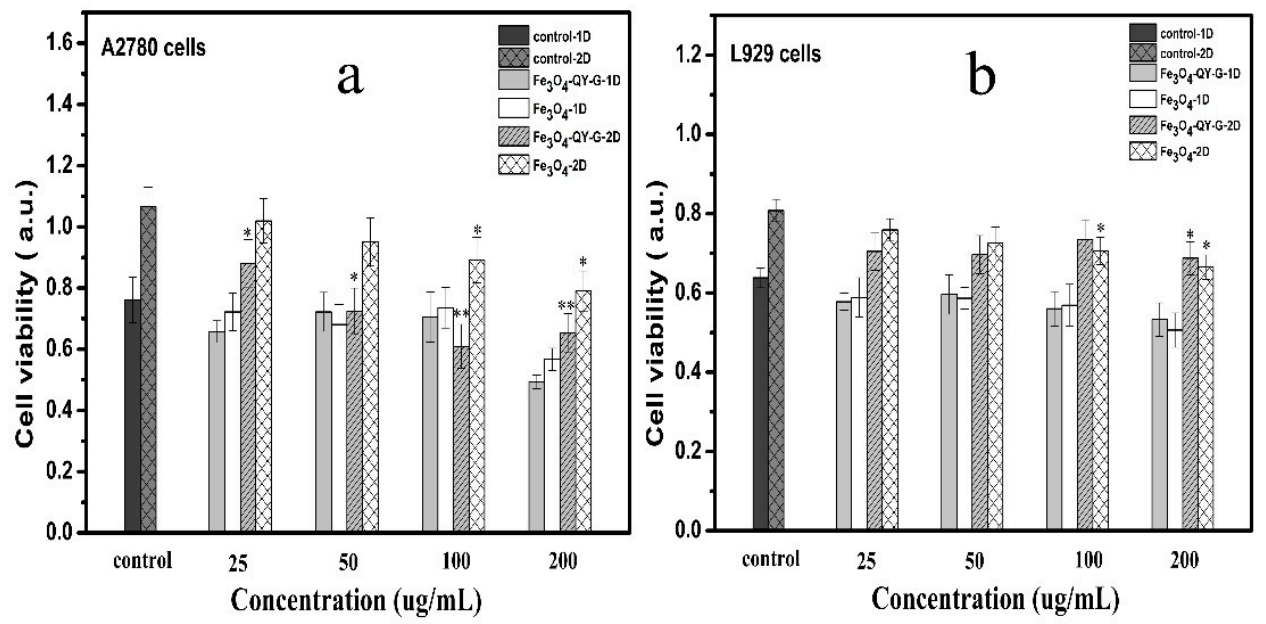

Figure 10. Effect of $\mathrm{Fe}_{3} \mathrm{O}_{4}-\mathrm{QY}-\mathrm{G}$ and $\mathrm{Fe}_{3} \mathrm{O}_{4}$ nanoparticles with different concentrations on the viability of (a) A2780 cells, (b) L929 cells. (* and ${ }^{* *}$ show significant differences between groups treated with control and nanoparticles. ${ }^{*} p<0.05,{ }^{* *} p<0.01$. Data are presented as means $\pm \mathrm{SD}, n=6$ ).

\section{Discussion}

The newly developed $\mathrm{Fe}_{3} \mathrm{O}_{4}$-QY-G nanoparticles in this study showed high $\mathrm{r}_{2}$ relaxivity and targeting ability. Unlike the $\mathrm{Fe}_{3} \mathrm{O}_{4}$ nanoparticles prepared in a one-pot strategy reported previously, these $\mathrm{Fe}_{3} \mathrm{O}_{4}$-QY-G nanoparticles possess a small particle size, superparamagnetism, and good dispersion stability. The presence of the additives can enhance, retard, or inhibit crystal nucleation, and therefore assist in the formation of a desired crystal habit. The key factors that determine the ability of an additive to modulate crystal nucleation are the strength of its interaction with the solute, its disruptive ability, interfacial properties, and the degree of self-association [40]. For additives with a high affinity for the solute, the solute molecules tend to conflict with the emerging solute lattice and hence cause nucleation inhibition. Since the shape and size of the inorganic particles are correlative to the formation process of crystal in biomimetic mineralization, we should bear these factors in mind when discussing the advance of this method.

Firstly, the overall physicochemical properties (e.g., charge density and hydrophilicity) of the amino acid active domain were speculated to be responsible for their impact in the biomineralization process [41-43], based on the premise that amino acid residue with hydrophilic side chains could interact with the lattice structure of the inorganic material. According to the peptide side chain groups shown in Table S1 (Supporting Information), the hydrophilic amino acids: glutamine $(\mathrm{Q})$, threonine $(\mathrm{T})$, asparagine $(\mathrm{N})$, serine $(\mathrm{S})$, lysine $(\mathrm{K})$, and tyrosine $(\mathrm{Y})$ account for $64.3 \%$ and the polar amino acids: $\mathrm{Q}, \mathrm{T}, \mathrm{S}, \mathrm{K}$, and $\mathrm{Y}$ account for $42.9 \%$, which indicated that the 14-mer peptide possessing hydrophilic side chains could interact with the lattice structure of $\mathrm{Fe}_{3} \mathrm{O}_{4}$ nanoparticles [44].

Secondly, the peptide worked synergistically with the ginger extract to actively control the biomimetic mineralization as a $\mathrm{Fe}_{3} \mathrm{O}_{4}$ nucleation inhibitor (Figure 11). In this system, hydroxyl-containing amino acids ( $\mathrm{T}, \mathrm{Y}$, and $\mathrm{S}$ ) and carboxyl-containing amino acids $(\mathrm{Q})$ can be regarded as hard Lewis bases and react with $\mathrm{Fe}^{3+}$, which was considered as a hard acid by the electrostatic interaction between the hard acid and the hard base [18]. Besides this, the chelating ability on $\mathrm{Fe}^{2+}$ of the ginger extract limited the migration of ions and caused them to disperse homogeneously (Figure 11, Step 1). This could make up for the fact that normally mineralized proteins only bind and disperse $\mathrm{Fe}^{3+}$. Another active ingredient in the process may be the polysaccharide (e.g., starch). The existence of the hydrogen bonds between the functional groups of polysaccharides and the oxygen atoms of the $\mathrm{Fe}_{3} \mathrm{O}_{4}$ (111) surface has been proven by the radial distribution function analysis [45], which may be the reason for the forming of a strong interaction. However, the appropriate reaction time and additive concentration did not significantly change the growth rate of different crystal facets, and the prepared nanoparticles remained spherical in this study. 
Based on the analysis presented above, the peptide and ginger extract performed as nucleation inhibitors by binding to the precursors, and would postpone the conversion of precursors to $\mathrm{Fe}_{3} \mathrm{O}_{4}$. As a consequence, $\mathrm{Fe}_{3} \mathrm{O}_{4}$ would be harvested at a higher $\mathrm{pH}$ condition due to the combination mentioned above, and the smaller crystal size would be produced because of the decrease in surface tension [46-48] (Figure 11, Step 2). Also, nucleation of iron oxide particulates occurs relatively free from interparticle interactions (e.g., aggregation) as a result of the templating action. Furthermore, the microstructure of the ginger extract is mainly composed of lamellaes and nets. The former consists of a dense alternating layer with a spacing of 3-5 $\mu \mathrm{m}$, whereas the latter consists of fibers less than $100 \mathrm{~nm}$ in diameter [22]. Therefore, in the microenvironment, the lamellaes and nets of ginger may limit the growth and aggregation space of the $\mathrm{Fe}_{3} \mathrm{O}_{4}$ crystal (Figure 11, Step 3). However, the more ginger extract was added, the lower the crystallinity was. When the amount reached $3 \mathrm{~mL}$ (containing $60 \mathrm{mg}$ of ginger extract powder), the crystallization could hardly be observed (Figure 12, Figure S2). This may be due to the chelating ability and reduction capability of the ginger extract, causing complete inhibition of crystallization.

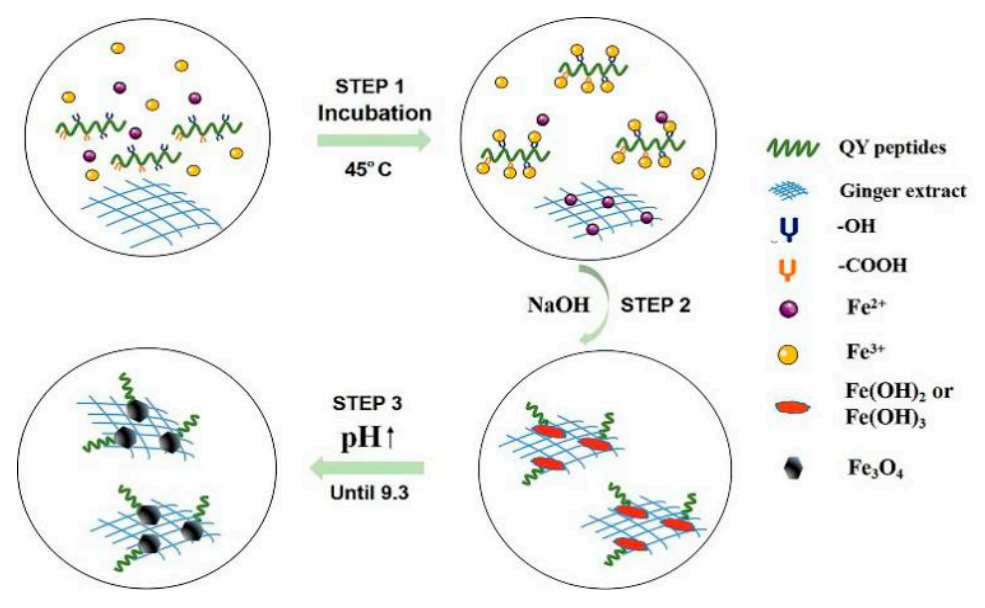

Figure 11. Possible formation mechanism of $\mathrm{Fe}_{3} \mathrm{O}_{4}-\mathrm{QY}-\mathrm{G}$ nanoparticles.
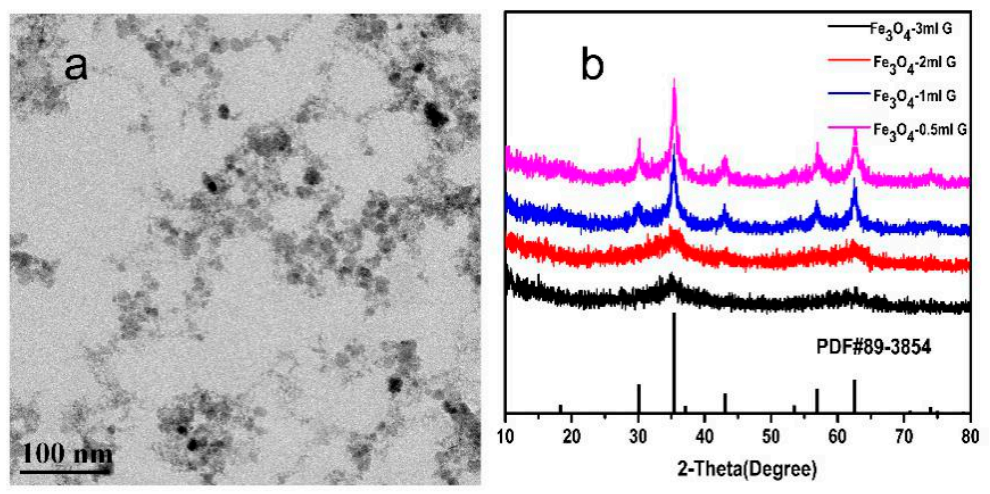

Figure 12. (a) TEM image of $\mathrm{Fe}_{3} \mathrm{O}_{4}$ nanoparticles prepared by adding $3 \mathrm{~mL}$ ginger extract, (b) XRD pattern of $\mathrm{Fe}_{3} \mathrm{O}_{4}$ nanoparticles prepared by adding different concentrations of ginger extract.

Finally, with the protonation/deprotonation of $\mathrm{K}$, the positively charged residues in the peptide could control the dispersion/precipitation of the particles, which affected the particle dispersion [49]. Under alkaline conditions of the reaction system $(\mathrm{pH}=9.3)$, the increase in electrostatic stabilization upon protonation of the $\mathrm{K}$ residues protects the particles against uncontrolled agglomeration. Meanwhile, the iron atoms in the surface of the $\mathrm{Fe}_{3} \mathrm{O}_{4}$ atomic lattice coordinated with water molecules in an aqueous solution, leading to the enrichment of hydroxyl groups $(-\mathrm{OH})$ on the surface of particles, and the binding of $\mathrm{C}=\mathrm{O}$ contained in the peptide to the hydroxyl terminated $\mathrm{Fe}_{3} \mathrm{O}_{4}$ surface via 
hydrogen bonds [50]. Hence, the presence of hydrogen bonds prolonged the protonation of $\mathrm{K}$ and improved the dispersibility of particles [51].

In summary, superparamagnetic and functionalized $\mathrm{Fe}_{3} \mathrm{O}_{4}$ nanoparticles were obtained under the mediation of a 14-mer peptide and ginger extract.

\section{Materials and Methods}

\subsection{Materials}

$\mathrm{FeCl}_{2} \cdot 4 \mathrm{H}_{2} \mathrm{O}, \mathrm{FeCl}_{3} \cdot 6 \mathrm{H}_{2} \mathrm{O}$, and $\mathrm{NaOH}$ were obtained from the Chengdu Kelong Chemical Reagent Factory (Chengdu, China). The 14-mer peptide (QQTNWSLTVNFKLY), synthesized by Shanghai Bootech BioScience and Technology Co., Ltd., was applied as a template. The ginger was bought in the local market (Chengdu, China). All reagents were of analytical grade and used directly without further purification, and aqueous solutions were used with deionized water $(18.25 \mathrm{M} \Omega \cdot \mathrm{cm}$ resistivity at $25^{\circ} \mathrm{C}$ ). L929 cells and A2780 cells were purchased from the Shanghai Institute of Biochemistry and Cell Biology (Shanghai, China), and Fenghui Biotechnologies Inc. (Changsha, China), respectively.

To prepare the ginger extract, the ginger $(250 \mathrm{~g})$ was cleaned and washed with distilled water and then cut into small pieces. The extraction of constituents was carried out using a water-ethanol solution ( $300 \mathrm{~mL}, 1: 1$ ratio) for 5 days at room temperature (in a dark location). Then the supernatant was vacuum filtered and freeze-dried to obtain the powder. The ginger extract solution $(20 \mathrm{mg} / \mathrm{mL})$ was prepared fresh and used right after it was ready.

\subsection{Preparation of $\mathrm{Fe}_{3} \mathrm{O}_{4}$ Nanoparticles}

14-mer peptide $(30,40,50$, and $60 \mathrm{mg})$ was dissolved in a solution $(50 \mathrm{~mL})$ that was ferric and ferrous (molar ratio $=2 / 1$ ) with a certain amount of ginger extract $(0.5,1,2$ and $3 \mathrm{~mL}$ ). After interacting for $30 \mathrm{~min}$ at $45{ }^{\circ} \mathrm{C}$ and in a $\mathrm{N}_{2}$ atmosphere, an appropriate volume of $\mathrm{NaOH}(25 \%)$ was dropwise added with dripping rate of 1-2 drop/s until the $\mathrm{pH}$ approximately reached 9.3. The reaction under this condition lasted for $5 \mathrm{~h}$, and following this the suspension was centrifuged. Then, the precipitates were washed with deoxygenated distilled water and absolute ethyl alcohol until the $\mathrm{pH}$ of washed water was at about 7 , and were then dried in a vacuum atmosphere. As the control, the $\mathrm{Fe}_{3} \mathrm{O}_{4}-\mathrm{QY}$ nanoparticles were prepared in the system without the ginger extract. Iron oxide of $\mathrm{Fe}^{2+}$ and $\mathrm{Fe}^{3+}$ were precipitated at an alkaline $\mathrm{pH}$ to get the desired $\mathrm{Fe}_{3} \mathrm{O}_{4} \mathrm{MNPs}$ as shown below:

$$
\mathrm{Fe}^{2+}+2 \mathrm{Fe}^{3+}+8 \mathrm{OH}^{-}=\mathrm{Fe}_{3} \mathrm{O}_{4} \downarrow+4 \mathrm{H}_{2} \mathrm{O}
$$

\subsection{Physicochemical Characterizations}

The phase composition was collected via XRD analysis using $\mathrm{Cu}-\mathrm{K} \alpha$ radiation $(\lambda=1.54060 \AA)$ over the $2 \theta$ range of $5-80^{\circ}$ at a rate of $5^{\circ} / \mathrm{min}$ with a Lab XRD-6100 diffractometer (Kyoto, Japan). The Raman scattering measurement was conducted at room temperature, and the excitation light was the $532 \mathrm{~nm}$ line. X-ray photoelectron spectroscopy (XPS, Escalab250Xi, Waltham, MA, USA) measurement was carried out to further verify the chemical composition. Transmission Electron Microscopy (Libra 200 FE, Oberkochen, Germany, operating at $200 \mathrm{kV}$ ) was used for characterizing the size and morphology of nanoparticles. The magnetic property was measured with a vibrating sample magnetometer (Lake shore-7400, Columbus, OH, USA) at room temperature. Thermal decomposition of the compound was studied from room temperature to $1000^{\circ} \mathrm{C}$ by differential scanning calorimetry (DSC) and thermogravimetric (TG) analysis at a heating rate of $10^{\circ} \mathrm{C} / \mathrm{min}$ in a dynamic argon atmosphere (STA449F3, Bavaria, Germany) (Supporting Information, Figure S3). FT-IR analysis was performed using the $\mathrm{KBr}$ method (Nicolet 6700, Waltham, MA, USA). The transverse relaxation times $\left(\mathrm{T}_{2}\right)$ and imaging ability of $\mathrm{Fe}_{3} \mathrm{O}_{4}-\mathrm{QY}-\mathrm{G}$ nanoparticles were measured for different concentrations of Fe using a 7 T MRI scanner (Bruker BioSpec 70/30, Billerica, MA, USA). Dynamic light scattering 
(DLS) measurement and zeta-potential measurements were performed using Zetasizer Nano ZS (Malvern, UK).

\subsection{The Chelating Ability on $\mathrm{Fe}^{2+}$ and Reduction Capability Test of $\mathrm{Fe}^{3+}$}

The chelating activity of the ginger extract on $\mathrm{Fe}^{2+}$ was carried out according to Juntachote's report [52]. Briefly, $1 \mathrm{~mL}$ samples of different concentrations $(0.1-2 \mathrm{mg} / \mathrm{mL})$ were diluted with $3.7 \mathrm{~mL}$ deionized water. Then, $0.1 \mathrm{~mL}$ of $\mathrm{FeCl}_{2}(2 \mathrm{mM})$ and $0.2 \mathrm{~mL}$ ferrozine $(5 \mathrm{mM})$ were added. Ferrozine can form a complex with free $\mathrm{Fe}^{2+}$ but not with $\mathrm{Fe}^{2+}$ bound by a chelating agent. After incubating for 10 min at room temperature, the absorbance of reaction mixtures was recorded at $562 \mathrm{~nm}$ in a Versa Max spectrophotometer (Bio-Rad, Hercules, CA, USA). The chelating activity was calculated according to the following expression equation:

$$
\text { Chelatingactivity }[\%]=1-\frac{A b s}{A b c} \times 100
$$

where $A b s$ and $A b c$ are the absorbance of sample and the measurement at $562 \mathrm{~nm}$, respectively.

The reducing capability of the ginger extract was measured according to Iris Hinneburg [53]. $1 \mathrm{~mL}$ samples of different concentrations $(0.1-2 \mathrm{mg} / \mathrm{mL})$ were incubated for $30 \mathrm{~min}$ at $50{ }^{\circ} \mathrm{C}$ with $2.5 \mathrm{~mL}$ phosphate buffer $(0.2 \mathrm{M}, \mathrm{pH} 6.6)$ and $2.5 \mathrm{~mL}$ aqueous potassium hexacyanoferrate $\mathrm{K}_{3}\left[\mathrm{Fe}(\mathrm{CN})_{6}\right]$ solution $(1 \%, w / v)$. The reaction was terminated by adding $2.5 \mathrm{~mL}$ trichloroacetic acid $(10 \%, w / v)$. Then, the mixture was centrifuged for $10 \mathrm{~min}$ at $3000 \mathrm{rpm}$. The supernatant $(2.5 \mathrm{~mL})$ was mixed with $2.5 \mathrm{~mL}$ distilled water and $0.5 \mathrm{~mL}$ ferric chloride $(0.1 \%, w / v)$. The absorbance was measured at $700 \mathrm{~nm}$ in a Versa Max spectrophotometer.

\subsection{In Vitro Cytotoxicity Study of $\mathrm{Fe}_{3} \mathrm{O}_{4}-\mathrm{QY}-\mathrm{G}$ Nanoparticles}

An MTT [3-(4,5-dimethyl-2-thiazolyl)-2,5-diphenyl-2Htetrazolium bromide] assay was performed to evaluate the cellular compatibility of $\mathrm{Fe}_{3} \mathrm{O}_{4}-\mathrm{QY}-\mathrm{G}$ nanoparticles. Cells were cultured in a 96-well plate (approximately $1 \times 10^{4}$ cells per well) with Dulbecco's Modified Eagle Medium (DMEM) containing 10\% neonatal calf serum (NCS) and different concentrations of the samples for $24 \mathrm{~h}$ and $48 \mathrm{~h}$. Subsequently, $20 \mu \mathrm{L}$ of MTT solution ( $5 \mathrm{mg} / \mathrm{mL}$ MTT in phosphate buffer solution) was added to each well and incubated for $4 \mathrm{~h}$ at $37^{\circ} \mathrm{C}$. After the medium was removed, $150 \mathrm{~mL}$ of dimethylsulfoxide (DMSO) was used to extract intracellular formazan crystals. The results were quantified by measuring the absorbance of the cell lysate at $490 \mathrm{~nm}$. All results were averages \pm SD of six samples.

\subsection{Cell Targeting Study of $\mathrm{Fe}_{3} \mathrm{O}_{4}-Q Y-G$ Nanoparticles}

Prussian blue staining was used to reveal the presence of iron cations. The A2780 and L929 cells were fixed with $4 \%$ formaldehyde after culturing with the $\mathrm{Fe}_{3} \mathrm{O}_{4}$-QY-G nanoparticles for $4 \mathrm{~h}$ and washed with phosphate buffer saline (PBS), followed by the incubation with 4 mL Prussian blue solution comprising an equal volume of $2 \%$ hydrochloric acid aqueous solution and $2 \%$ potassium ferrocyanide (II) trihydrate for $30 \mathrm{~min}$. Finally, the iron staining was observed using a microscope (Olympus IX71, Japan) after being washed three times with PBS.

L929 and A2780 cells were cultured in a Petri dish $(\Phi=100 \mathrm{~mm})$ with a density of $4 \times 10^{5}$ cells per Petri dish. After plating, the cells were washed three times with PBS, and the solution of nanoparticles was added with a concentration of $100 \mu \mathrm{g} / \mathrm{mL}$. The cells were incubated for $24 \mathrm{~h}$ and washed three times with PBS to remove extra nanoparticles. After detaching by trypsin solution, the detached cells were counted and then prepared for ICP-OES (Agilent ICPOES730, Santa Clara, CA, USA).

\subsection{Statistical Analysis}

Statistical comparisons were made by analysis of variance (ANOVA). The mean \pm standard deviation was calculated in each experiment $(n=6)$, with statistical significance considered when $p \leq 0.05$. 


\section{Conclusions}

In this work, the 14-mer peptide capable of specific binding to both $\mathrm{Fe}_{3} \mathrm{O}_{4}$-MNPs and tumor cells was used to control the morphology and size of $\mathrm{Fe}_{3} \mathrm{O}_{4}$ in process of biomimetic mineralization. Ginger extract was used as antioxidant and chelator to collaborate in the biomimetic mineralization process. The obtained $\mathrm{Fe}_{3} \mathrm{O}_{4}-\mathrm{QY}-\mathrm{G}$ nanoparticles are of superparamagnetism and presented good MRI imaging efficiency. Cell viability and targeting tests showed $\mathrm{Fe}_{3} \mathrm{O}_{4}-\mathrm{QY}-\mathrm{G}$ nanoparticles can not only suppress the growth of A2780 cells but also target to them. In conclusion, the $\mathrm{Fe}_{3} \mathrm{O}_{4}$-QY-G nanoparticles may have potential application in targeting tumor therapy or angiography.

Supplementary Materials: Table S1: Side chain functional groups contained in 14-mer peptide. Figure S1: (a) XRD pattern of $\mathrm{Fe}_{3} \mathrm{O}_{4}$-TVN and $\mathrm{Fe}_{3} \mathrm{O}_{4}$-SVE nanoparticles, (b) TEM image of $\mathrm{Fe}_{3} \mathrm{O}_{4}$-TVN nanoparticles, (c) TEM image of $\mathrm{Fe}_{3} \mathrm{O}_{4}$-SVE nanoparticles. Figure S2: TEM images of $\mathrm{Fe}_{3} \mathrm{O}_{4}$ nanoparticles prepared by adding different concentrations of ginger extract: (a) $3 \mathrm{~mL}$, (b) $2 \mathrm{~mL}$, (c) $1 \mathrm{~mL}$, (d) $0.5 \mathrm{~mL}$. Figure S3. TG and DSC curves of (a) $\mathrm{Fe}_{3} \mathrm{O}_{4}$ nanoparticles (b) $\mathrm{Fe}_{3} \mathrm{O}_{4}$-QY nanoparticles (c) $\mathrm{Fe}_{3} \mathrm{O}_{4}$-QY-G nanoparticles. Figure S4. TEM images of $\mathrm{Fe}_{3} \mathrm{O}_{4}$ nanoparticles prepared by adding different amount of peptide (a) $30 \mathrm{mg}$, (b) $40 \mathrm{mg}$, (c) $50 \mathrm{mg}$, (d) $60 \mathrm{mg}$; (e) XRD pattern of $\mathrm{Fe}_{3} \mathrm{O}_{4}$ nanoparticles prepared by adding different amount of peptide.

Author Contributions: L.L. and X.P. proposed the experimental concept; L.L., J.Y., Y.W., and X.C. performed the experiments; L.L. wrote the paper; L.L. and X.P. analyzed the experimental data; G.Y. and X.P. reviewed and edited the paper.

Funding: This research was funded by the Sichuan Science and Technology Program, grant number 2017JY0255, and the Key Scientific and Technological Funds from Zigong City, grant number 2016XC11.

Conflicts of Interest: The authors declare no conflict of interest. The funders had no role in the design of the study.

\section{References}

1. Mohapatra, M.; Anand, S. Synthesis and applications of nano-structured iron oxides/hydroxides-A review. Int. J. Eng. Sci. 2010, 2, 127-146. [CrossRef]

2. Darja, L.; Alenka, M. Anisotropic magnetic nanoparticles: A review of their properties, syntheses and potential applications. Prog. Mater. Sci. 2018, 95, 286-328.

3. Ma, M.; Wu, Y.; Zhou, J.; Sun, Y.K.; Zhang, Y.; Gu, N. Size dependence of specific power absorption of $\mathrm{Fe}_{3} \mathrm{O}_{4}$ particles in AC magnetic field. J. Magn. Magn. Mater. 2004, 268, 33-39. [CrossRef]

4. Heba, M.Y.; Fatma, M.M.; Mariam, H.M.; Amira, B.E.M.; Asmaa, M.A.; Asmaa, A.A.; Maha, A.M.; Faten, A.M. Review of Green Methods of Iron Nanoparticles Synthesis and Applications. BioNanoScience 2018, 8, 1-13.

5. Xie, S.; Yin, G.; Pu, X.; Hu, Y.; Huang, Z.; Liao, X.; Chen, X. Biomimetic Mineralization of Tumor Targeted Ferromagnetic Iron Oxide Nanoparticles Used for Media of Magnetic Hyperthermia. Curr. Drug Deliv. 2017, 14, 349-356. [CrossRef] [PubMed]

6. Lenders, J. Biomimetic Macromolecule-Mediated Magnetite Mineralization; Technische Universiteit Eindhoven: Eindhoven, The Netherlands, 2015.

7. Yang, W.; Guo, W.; Chang, J.; Zhang, B. Protein/peptide-templated biomimetic synthesis of inorganic nanoparticles for biomedical applications. J. Mater. Chem. B 2017, 5, 401-417. [CrossRef]

8. Zhang, B.; Wang, J.; Yu, J.; Fang, X.; Wang, X.; Shi, D. Site-Specific Biomimetic Precision Chemistry of Bimodal Contrast Agent with Modular Peptides for Tumor-Targeted Imaging. Bioconjug. Chem. 2017, 28, 330-335. [CrossRef]

9. Yang, W.; Wu, X.; Dou, Y.; Chang, J.; Xiang, C.; Yu, J.; Wang, J.; Wang, X.; Zhang, B. A human endogenous protein exerts multi-role biomimetic chemistry in synthesis of paramagnetic gold nanostructures for tumor bimodal imaging. Biomaterials 2018, 161, 256-269. [CrossRef] [PubMed]

10. Yang, W.; Shi, X.; Shi, Y.; Yao, D.; Chen, S.; Zhou, X.; Zhang, B. Beyond the Roles in Biomimetic Chemistry: An Insight into the Intrinsic Catalytic Activity of an Enzyme for Tumor-Selective Phototheranostics. ACS Nano 2018, 12, 12169-12180. [CrossRef] [PubMed]

11. Wang, L.; Tanya, P.; Pierre, E.; Liu, X.; David, V.; Ruslan, P.; Surya, M.; Marit, N. Self-Assembly and Biphasic Iron-Binding Characteristics of Mms6, A Bacterial Protein That Promotes the Formation of Superparamagnetic Magnetite Nanoparticles of Uniform Size and Shape. Biomacromolecules 2011, 13, 98-105. [CrossRef] [PubMed] 
12. Larken, E.E.; Stephanie, G.G.; Stephen, O.B.; Timothy, J.D.; Galen, D.S.; C, B.M.; G, A.H. Cooperative Assembly of Magnetic Nanoparticles and Block Copolypeptides in Aqueous Media. Nano Lett. 2003, 3, 1489-1493.

13. Wei, Y.; Yin, G.; Ma, C.; Huang, Z.; Chen, X.; Liao, X.; Yao, Y.; Yin, H. Synthesis and cellular compatibility of biomineralized $\mathrm{Fe}_{3} \mathrm{O}_{4}$ nanoparticles in tumor cells targeting peptides. Colloid Surf. B 2013, 107, 180-188. [CrossRef]

14. Mackay, J.A.; Chen, M.; Mcdaniel, J.R.; Liu, W.; Simnick, A.J.; Chilkoti, A. Self-assembling chimeric polypeptide-doxorubicin conjugate nanoparticles that abolish tumours after a single injection. Nat. Mater. 2009, 8, 993-999. [CrossRef]

15. Nowsheen, G.; Archana, B.L.; Gary, L.B.; Dhanjay, J. An assessment of biopolymer- and synthetic polymer-based scaffolds for bone and vascular tissue engineering. Polym. Int. 2003, 62, 523-533.

16. Senapati, S.; Ahmad, A.; Khan, M.I.; Sastry, M.; Kumar, R. Extracellular biosynthesis of bimetallic Au-Ag alloy nanoparticles. Small 2010, 1, 517-520. [CrossRef]

17. Zayed, M.F.; Eisa, W.H.; Shabaka, A.A. Malva parviflora extract assisted green synthesis of silver nanoparticles. Spectrochim. Acta A 2012, 98, 423-428. [CrossRef]

18. Bindhu, M.R.; Umadevi, M. Synthesis of monodispersed silver nanoparticles using Hibiscus cannabinus leaf extract and its antimicrobial activity. Spectrochim. Acta A 2013, 101, 184-190. [CrossRef]

19. Kumar, K.P.; Paul, W.; Sharma, C.P. Green synthesis of gold nanoparticles with Zingiber officinale extract: Characterization and blood compatibility. Process. Biochem. 2011, 46, 2007-2013. [CrossRef]

20. Nile, S.H.; Park, S.W. Chromatographic analysis, antioxidant, anti-inflammatory, and xanthine oxidase inhibitory activities of ginger extracts and its reference compounds. Ind. Crop. Prod. 2015, 70, 238-244. [CrossRef]

21. Shukla, Y.; Singh, M. Cancer preventive properties of ginger: A brief review. Food Chem. Toxicol. 2007, 45, 683-690. [CrossRef]

22. Olena, I.; Jacek, G.; Barbara, P.; ucja, P.; Tomasz, Z.; Grzegorz, N.; Marcin, J.; Anna, M.G.; Stefan, J. Self-organizing silver and ultrasmall iron oxide nanoparticles prepared with ginger rhizome extract: Characterization, biomedical potential and microstructure analysis of hydrocolloids. Mater. Des. 2017, 133, 307-324.

23. You, F.; Yin, G.; Pu, X.; Li, Y.; Hu, Y.; Huang, Z.; Liao, X.; Yao, Y.; Chen, X. Biopanning and characterization of peptides with $\mathrm{Fe}_{3} \mathrm{O}_{4}$ nanoparticles-binding capability via phage display random peptide library technique. Colloid Surf. B 2016, 141, 537-545. [CrossRef]

24. Zhang, L.; Xie, W.; Zhao, X.; Liu, Y.; Gao, W. Study on the morphology, crystalline structure and thermal properties of yellow ginger starch acetates with different degrees of substitution. Thermochim. Acta 2009, 495, $57-62$.

25. Soumya, D.; Hendry, M.J. Application of Raman spectroscopy to identify iron minerals commonly found in mine wastes. Chem. Geol. 2011, 290, 101-108.

26. Li, Y.; Church, J.S.; Woodhead, A.L. Infrared and Raman spectroscopic studies on iron oxide magnetic nano-particles and their surface modifications. J. Magn. Magn. Mater. 2012, 324, 1543-1550. [CrossRef]

27. Slavov, L.; Abrashev, M.V.; Merodiiska, T.; Gelev, C.; Vandenberghe, R.E.; Markova-Deneva, I. Raman spectroscopy investigation of magnetite nanoparticles in ferrofluids. J. Magn. Magn. Mater. 2010, 322, 1904-1911. [CrossRef]

28. Guo, C.; Hu, Y.; Qian, H.; Ning, J.; Xu, S. Magnetite $\left(\mathrm{Fe}_{3} \mathrm{O}_{4}\right)$ tetrakaidecahedral microcrystals: Synthesis, characterization, and micro-Raman study. Mater. Charact. 2011, 62, 148-151. [CrossRef]

29. Aliahmad, M.; Nasiri, M.N. Synthesis of maghemite $\left(\gamma-\mathrm{Fe}_{2} \mathrm{O}_{3}\right)$ nanoparticles by thermal-decomposition of magnetite $\left(\mathrm{Fe}_{3} \mathrm{O}_{4}\right)$ nanoparticles. Mater. Sci. 2013, 31, 264-268. [CrossRef]

30. Yeh, H.Y.; Chuang, C.H.; Chen, H.C.; Wan, C.J.; Chen, T.L.; Lin, L.Y. Bioactive components analysis of two various gingers (Zingiber officinale Roscoe) and antioxidant effect of ginger extracts. LWT-Food Sci. Technol. 2014, 55, 329-334. [CrossRef]

31. Aicha, J.; Ângela, F.; Lillian, B.; Hassiba, C.; Lotfi, A.; Isabel, F.; Hassen, B.C. Chemical and antioxidant parameters of dried forms of ginger rhizomes. Ind. Crop. Prod. 2015, 77, 30-35.

32. Payne, K.J.; Veis, A. Fourier Transform IR Spectroscopy of Collagen and Gelatin Solutions: Deconvolution of the Amide I Band for Conformational Studies. Biopolymers 1988, 27, 1749-1760. [CrossRef] 
33. Kang, H.J.; Fasséli, C.; Fiona, C.; Thomas, P.; Edward, N.B. Stabilizing Isopeptide Bonds Revealed in Gram-Positive Bacterial Pilus Structure. Science 2007, 318, 1625-1628. [CrossRef]

34. Bijan, Z.; Mark, H. Spontaneous Intermolecular Amide Bond Formation between Side Chains for Irreversible Peptide Targeting. J. Am. Chem. Soc. 2010, 132, 4526-4527.

35. Jonathan, M.B.; Luciano, A.M.; Puneet, S.; Julian, P.W.; Kym, F.F.; Olaf, S. Amide bonds assemble pili on the surface of bacilli. Proc. Natl. Acad. Sci. USA 2008, 105, 10215-10220.

36. Barick, K.C.; Aslam, M.; Lin, Y.P.; Bahadur, D.; Prasad, P.V.; Dravid, V.P. Novel and efficient MR active aqueous colloidal $\mathrm{Fe}_{3} \mathrm{O}_{4}$ nanoassemblies. J. Mater. Chem. 2009, 19, 7023-7029. [CrossRef]

37. Barick, K.C.; Hassan, P.A. Glycine passivated $\mathrm{Fe}_{3} \mathrm{O}_{4}$ nanoparticles for thermal therapy. Colloid Surf. A 2012, 369, 96-102. [CrossRef]

38. Chen, X.Y.; Ahn, D.U. Antioxidant activities of six natural phenolics against lipid oxidation induced by $\mathrm{Fe}^{2+}$ or ultraviolet light. J. Am. Oil Chem. Soc. 1998, 75, 1717-1721. [CrossRef]

39. Oyaizu, M. Studies on products of browning reaction: Antioxidative activity of products of browning reaction. Jpn. J. Nutr. 1986, 44, 307-315. [CrossRef]

40. Song, R.Q.; Cölfen, H. Additive controlled crystallization. CrystEngComm 2011, 13, 1249-1276. [CrossRef]

41. Evans, J.S. "Tuning in" to Mollusk Shell Nacre- and Prismatic-Associated Protein Terminal Sequences. Implications for Biomineralization and the Construction of High Performance Inorganic? Organic Composites. Chem. Rev. 2008, 108, 4455-4462. [CrossRef]

42. Graeme, K.H.; Jason, O.Y.; Bernd, G.; Mikko, K.; Harvey, A.G. The Flexible Polyelectrolyte Hypothesis of Protein-Biomineral Interaction. Langmuir 2010, 26, 18639-18646.

43. Lajos, K.; Daniel, H.; Gabor, V.; Peter, T. Structural disorder in proteins brings order to crystal growth in biomineralization. Bone 2012, 51, 528-534.

44. Beverly, D.B.; Marc, R.K. Nanotechnology Meets Biology: Peptide-based Methods for the Fabrication of Functional Materials. J. Phys. Chem. Lett. 2012, 3, 405-418.

45. Qiang, L.; Yang, T.; Li, Z.; Wang, H.; Chen, X.; Cui, X. Molecular dynamics simulations of the interaction between $\mathrm{Fe}_{3} \mathrm{O}_{4}$ and biocompatible polymer. Colloid Surf. A 2014, 456, 62-66. [CrossRef]

46. Jens, B.; Archan, D.; Paul, H.B.; Cécile, L.C.; Peter, F.; Nico, A.S.; Damien, F. Nucleation and growth of magnetite from solution. Nat. Mater. 2013, 12, 310-314.

47. Jens, B.; Maria, A.C.; Kevin, M.E.; Peter, W.; Damien, F. Biomimetic Magnetite Formation: From Biocombinatorial Approaches to Mineralization Effects. Langmuir 2014, 30, 2129-2136.

48. Lionel, V.; Corinne, C.; Elisabeth, T.; Jean, P.J. Size Tailoring of Magnetite Particles Formed by Aqueous Precipitation: An Example of Thermodynamic Stability of Nanometric Oxide Particles. J. Colloid Interface Sci. 1998, 205, 205-212.

49. Lenders, J.J.M.; Zope, H.R.; Yamagishi, A.; Bomans, P.H.H.; Arakaki, A.; Kros, A.; Sommerdijk, N.A.S. Bioinspired magnetite crystallization directed by random copolypeptides. Adv. Funct. Mater. 2015, 25, 711-719. [CrossRef]

50. Christer, B.A.; Kenneth, R.S. The hydrogen bond and crystal engineering. Chem. Soc. Rev. 1993, 22, 397-407.

51. Borisenko, V.; Sansom, M.S.P.; Woolley, G. Protonation of Lysine Residues Inverts Cation/Anion Selectivity in a Model Channel. Biophys. J. 2000, 78, 1335-1348. [CrossRef]

52. Juntachote, T.; Berghofer, E. Antioxidative properties and stability of ethanolic extracts of Holy basil and Galangal. Food Chem. 2005, 92, 193-202. [CrossRef]

53. Iris, H.; Damien, D.H.J.; Raimo, H. Antioxidant activities of extracts from selected culinary herbs and spices. Food Chem. 2006, 97, 122-129.

Sample Availability: Samples of the compounds are not available from the authors. 